\title{
Growth and earliness of Chinese cabbage (Brassica rapa var. chinensis) as a function of time and weather conditions
}

\author{
Andrzej Kalisz \\ Department of Vegetable and Medicinal Plants \\ University of Agriculture in Krakow \\ 29 Listopada 54, 31-425 Kraków, Poland \\ e-mail: a.kalisz@ur.krakow.pl
}

\begin{abstract}
The aim of the research, which was carried out in the years 2003-2005, was to assess the possibility of creating regression models for the earliness of Chinese cabbage (Brassica rapa var. chinensis, pak choy) plants cultivated under field conditions during the summer-autumn months. Four variables were chosen for developing the prediction model: the minimum, mean and maximum air temperatures and sunshine hours. After stepwise regression analysis, it was noted that crop earliness could be described as a function of mean air temperature and sunshine hours. For this model, the coefficient of determination $\mathrm{R}^{2}$ was equal to 0.962 . Additional models based on various thermal indices - growing degree days (GDD), heliothermal units (HTU) and photothermal units (PTU) - were also constructed and taken into consideration. The linear regression equation that includes GDD could only simulate the earliness of the plants with a precision below $14 \%$. The model built on the basis of PTU showed a better fit of the predicted data to the observed data (around 49\%), while the last model, which incorporated HTU, was the most accurate ( $\mathrm{R}^{2}$ was equal to 0.843 ). Models for the growth of pak choy plants in the field based on a time variable are also presented in this paper.
\end{abstract}

Key words: pak choy, time models, weather-crop modelling, harvest prediction

\section{INTRODUCTION}

Pak choy (Brassica rapa var. chinensis) plants belong to a group of vegetable crops derived from the Far East. It is a very popular vegetable in China that is also widely known in the USA. European countries have already made a number of attempts to introduce this plant to the consumer market (Granges 1989, Siomos 1999). The initial stage of starting a large-scale cultivation of vegetables from other parts of the world is to check their response to the target soil or climatic conditions, which are often different from the originating regions (Siomos 1999, Kalisz 2004). Understanding the response of the plants to the environmental conditions can be made on the basis of empirical observations and analysis of variance (Martyniak-Przybyszewska
2000, Kalisz 2004, Francescangeli et al. 2006, Kurtar 2006). This allows us to estimate with relatively high accuracy the response of vegetable species to the growing conditions of the particular region of the world in which this type of research is conducted. However, using correlation or regression analysis leads to a more complementary exploration of these issues. The aim of this type of analysis is to create predictive models or to develop existing models that can determine which environmental factors have the greatest influence on the growth and development of the crops (Hoogenboom 2000, Niedbała et al. 2007). Moreover, using such models make it possible to predict the developmental phases of vegetable plants (Grevsen and Olesen 1994, Grevsen and Olesen 1999, Tan et al. 2000b, 
Dufault et al. 2009). In the initial regression equations, typical weather parameters may be considered (Hoogenboom 2000, Francescangeli et al. 2004, Niedbała et al. 2007, Dufault et al. 2009). In the case of pak choy, the use of temperature and sunshine values for the growing season of the crop in the field can be a good solution. This leads to the development of simplified models. Their main task could be to predict the plants' yielding, for example. Similar models were developed by Dufault et al. (2009) for Romaine lettuce.

The input parameter for the predictive models can also be growing degree days (GDD), which is calculated as the sum of effective temperatures, i.e. those above the base temperature, which affect the rate of the plants' growth and development (McMaster and Wilhelm 1997, Everaarts 1999, Wurr et al. 2002). Regression equations that contain the growing degree days as a computable part can often accurately predict the course of phenological phases of the plants (Marcelis et al. 1998, Tan et al. 2000b, Cho and Son 2007). Degree days are frequently used to forecast the earliness of vegetables - in other words, the date of the first harvest (Everaarts 1999, Kurtar 2006). This type of model is not sufficient in all cases. This may be due to an incorrect matching of base temperature for a specific species, and even particular cultivars (Tan et al. 2000b, Francescangeli et al. 2004). It is obvious that the development of the plants is affected not only by temperature, but also by sunlight. Hence, this environmental factor is often included in the regression analysis (Tei et al. 1996a, Wurr et al. 1996, Marcelis et al. 1998, Olesen and Grevsen 2000, Francescangeli et al. 2006). To estimate the influence of light on the plants, such agro-meteorological indices as heliothermal and photothermal units can be used (Bazgeer et al. 2006). Heliothermal unit (HTU) for a given day represents the product of GDD and the actual hours of sunshine for that day, while photothermal unit (PTU) represents the product of GDD and the possible sunshine hours (Kumar et al. 2008).

The aim of the present study of the Brassica rapa var. chinensis was to develop and assess the accuracy of regression models. The above-described agro-meteorological parameters and indices were taken into account. Models of pak choy growth in the field based on time were also built.

\section{MATERIAL AND METHODS}

The field experiment was conducted during the summer/autumn crop-growing season of 2003-
2005 at the experimental station of the University of Agriculture in Krakow, Poland, on typical brown soil, formed from stabilised river alluvial soil. The following cultivars of non-heading Chinese cabbage (Brassica rapa var. chinensis, pak choy) were tested: 'Taisai', 'Pak Choy White' and 'Green Fortune' $F_{1}$. The plants were grown from transplants in two growing periods. Each year, plantings were made in the middle of August and at the end of that month. The first pak choy harvests usually took place in the middle of September (in the $1^{\text {st }}$ term of production) and in the first 10 days of October (in the $2^{\text {nd }}$ term), i.e. $31-34$ or $43-48$ days after transplanting, respectively.

Weather components (air temperature and sunshine hours) were recorded automatically. The HOBO RH/Temp. data loggers (Onset Computer Corp., USA) were used for recording the temperature (daily mean temperature and its extreme values). They were placed on the experimental plots. Sunshine hours were assessed at the meteorological station at Kraków-Balice, located close to the experimental field. Meteorological data were averaged for the particular growing periods of the pak choy plants. The maximum, mean, minimum air temperature and sunshine hours in the crop growing periods ranged from $19.9-26.5^{\circ} \mathrm{C}, 12.0-17.7^{\circ} \mathrm{C}, 5.3-10.7^{\circ} \mathrm{C}$ and 6.0 8.3 hours, respectively. The plants were sprinkler irrigated as needed, and for this reason precipitation was not taken into consideration.

Statistical calculations of the obtained results were performed with the use of the Advanced Linear/Nonlinear Models module of STATISTICA (data analysis software system), StatSoft, Inc. (USA). Multiple linear regression analysis (verified at $\mathrm{p}<0.05$ ), with backward elimination, was conducted to find the climatic variables which most significantly influenced the estimated yielding earliness. The thermal time (growing degree days, GDD), heliothermal units (HTU) and photothermal units (PTU) were calculated for the prediction of harvest times, according to formulas published by McMaster and Wilhelm (1997) and Bazgeer et al. (2006). The following mathematical formulas were used:

$$
\begin{aligned}
& \mathrm{GDD}=\Sigma\left(\mathrm{T}_{\text {avg }}-\mathrm{T}_{\text {base }}\right) ; \text { if } \mathrm{T}_{\text {avg }}<\mathrm{T}_{\text {base }} \text {, then } \mathrm{T}_{\text {avg }}=\mathrm{T}_{\text {base }} \\
& \mathrm{HTU}=\Sigma(\mathrm{GDD} \times \mathrm{H}) \\
& \mathrm{PTU}=\Sigma(\mathrm{GDD} \times \mathrm{P}),
\end{aligned}
$$

where $\mathrm{T}_{\text {avg }}$ was daily air temperature, $\mathrm{T}_{\text {base }}=$ $5.0^{\circ} \mathrm{C}, \mathrm{H}$ was actual sunshine hours and $\mathrm{P}$ was maximum possible sunshine hours (this parameter corresponded to the length of the day). The linear 
regression models of pak choy growth based on time (DAT - days after transplanting) were also proposed, separately for the tested cultivars and growing periods. The models were created for the prediction of plant height and rosette diameter changes over time, independent from the others environmental indices. Twenty plants from each experimental treatment were chosen to determine plant height and diameter, and then obtained data were averaged. The height was measured from the soil surface to the highest top of the rosettes. The diameter was estimated at the widest part of the rosette, and the measurement line was always carried out over its centre. The resulting regression models presented in this paper were characterised by the multiple coefficient of regression $R$, coefficient of determination $\left(R^{2}\right)$, adjusted coefficient of determination $\left(\mathrm{R}_{\text {adj }}^{2}\right)$, standard error of estimation $\left(\mathrm{SE}_{\mathrm{e}}\right)$ and also other statistics parameters (B - standardised regression coefficient, $\beta$ - beta regression coefficient, and their standard errors). For time models, only $\mathrm{R}$ and $\mathrm{R}^{2}$ were estimated and presented in this paper.

\section{RESULTS AND DISCUSSION}

The most important production stages of Brassica rapa var. chinensis are illustrated in Figure 1. The seedling production period lasted approximately three to four weeks and showed little variation between the growing terms. It was the shortest in 2003 (22-23 days), while in other years it was 2627 days long. The stronger response of the plants to the growing period was observed after their transplanting to the field. Pak choy planted in late August had a decidedly longer growing season than in the earlier production. For these plants, the number of days from planting to harvest exceeded 40 days, and the longest vegetation period of the plants was observed in 2003. Pak choy planted in mid-August reached maturity much more quickly. The acceleration of harvests in the subsequent years was 14,13 and 12 days in comparison to the later growing period. This indicates a very strong reaction of pak choy to different types of weather conditions in the different years of cultivation and specific production periods. According to Granges (1989) and Siomos (1999), pak choy belongs to the group of fast-growing plants. This usually allows to obtain high yields from that crop in a relatively short time. Granges (1989) reported that pak choy harvests began after about 50 days for plantings in September, while plantings in March and June resulted in a shortening of the growing period to about 40 and 30 days, respectively. The impact of weather on the course of the growth of plants cultivated at different periods was also observed by Siomos (1999) for pak choy cabbage, by Cebula et al. $(2003,2005)$ for cauliflowers (white, green and romanesco), by Tan et al. (2000a, 2000b) for broccoli, by Kurtar (2006) for Brussels sprouts and by Martyniak-Przybyszewska (2000) for heading Chinese cabbage.

Changes in the size of pak choy rosettes during the growth in the field are shown in Figures 2 and 3.

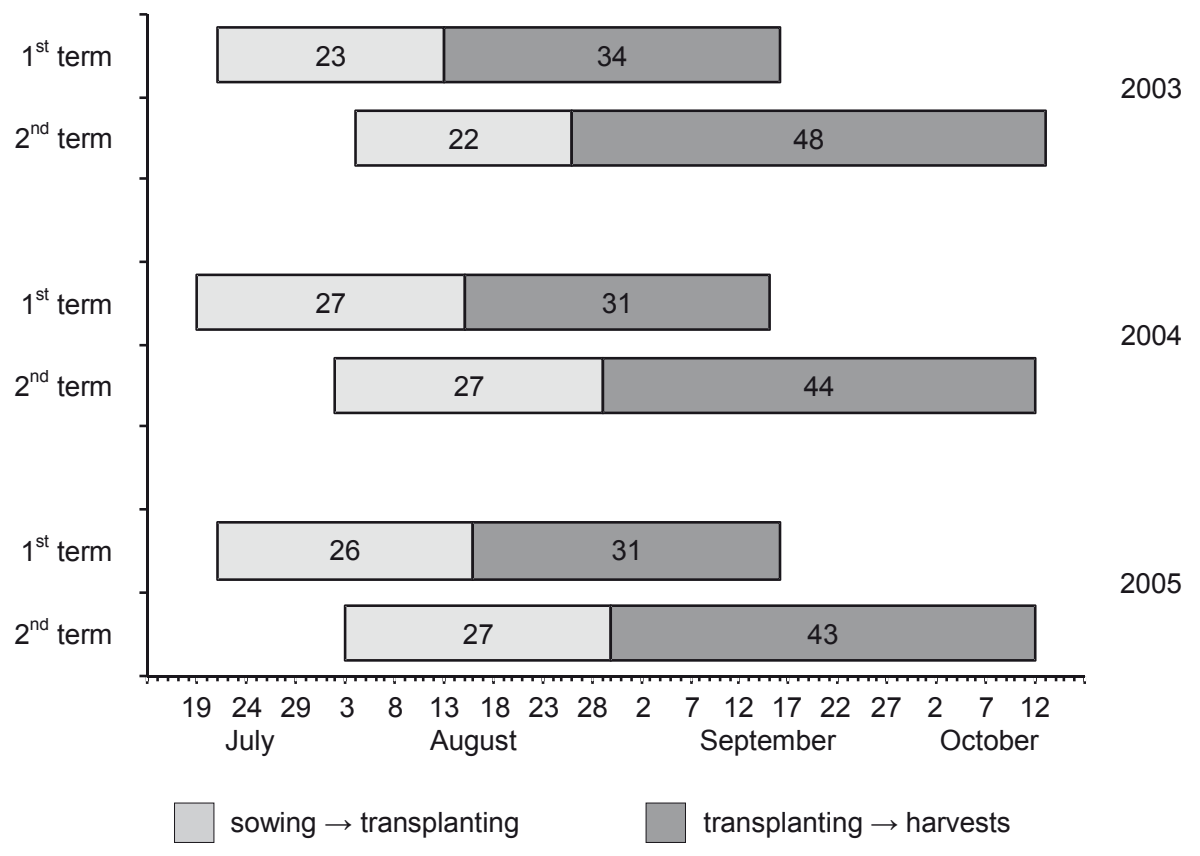

Figure 1. Pattern of production stages of pak choy in the years 2003-2005 (numbers inside bars represent days) 


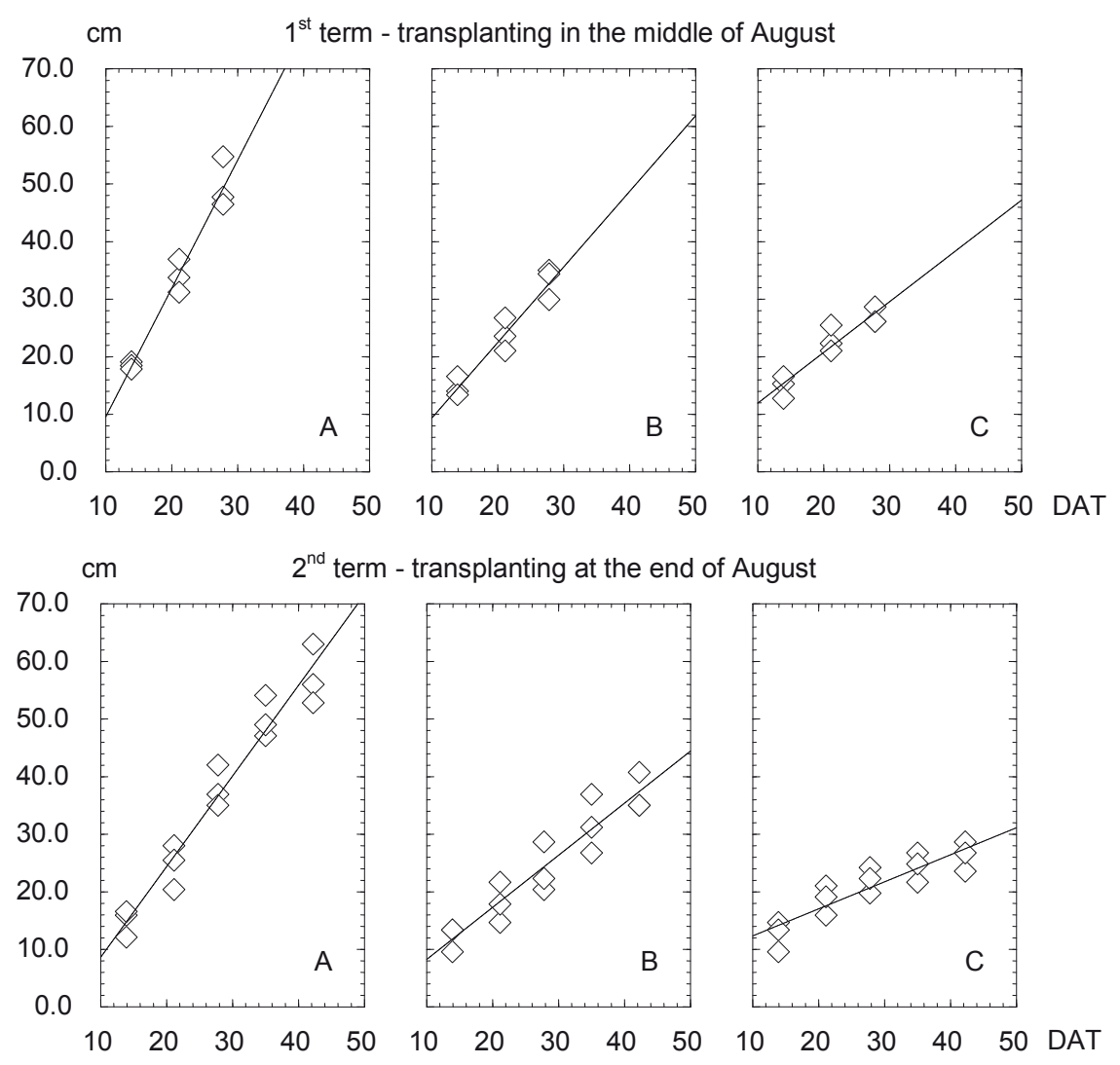

Figure 2. Height of pak choy plants over time (DAT - days after transplanting) during field vegetation: A - 'Taisai', B - 'Pak Choy White', C - 'Green Fortune' $F_{1}$

Directly after transplanting, the height of the plants' rosettes was similar. With the passage of time, the impact of the genetic factor for this biometric parameter was clearly indicated. In the final stage of cultivation, plants of 'Taisai' were always higher than those of 'Pak Choy White', while those of 'Green Fortune' $F_{1}$ were the lowest. In the second growing period, the plants had a greater amount of time to form higher rosettes than in the earlier production. The exception was the 'Green Fortune' $F_{1}$ cultivar, which had a similar rosette size at the end of the two production cycles. Regression analysis applied to data obtained from the experiments has brought the possibility of modelling the changes in rosette height over time separately for the cultivars and two production periods. Thus, in the first growing term, the rosette height (y) can be predicted on the basis of the following regression equations: 'Taisai' $\mathrm{y}=-12.7417+2.2283 * \mathrm{DAT}$ $\left(\mathrm{R}=0.982 ; \mathrm{R}^{2}=0.965\right)$, 'Pak Choy White' $\mathrm{y}=$ $-3.8172+1.3126 *$ DAT $\left(\mathrm{R}=0.970 ; \mathrm{R}^{2}=0.941\right)$, and 'Green Fortune' $\mathrm{F}_{1} \mathrm{y}=3.1033+0.8814 * \mathrm{DAT}$ $\left(\mathrm{R}=0.942 ; \mathrm{R}^{2}=0.887\right)$, where DAT - days after transplanting. In the next term of cultivation, they have the following forms: 'Taisai' $y=-7.1373+$ 1.5743 *DAT $\left(\mathrm{R}=0.976 ; \mathrm{R}^{2}=0.953\right)$, 'Pak Choy
White' $\mathrm{y}=-0.8147+0.9047 * \mathrm{DAT}\left(\mathrm{R}=0.945 ; \mathrm{R}^{2}\right.$ $=0,894)$, and for 'Green Fortune' $\mathrm{F}_{1} \mathrm{y}=7.6287+$ $0.4697 *$ DAT $\left(\mathrm{R}=0.887 ; \mathrm{R}^{2}=0.788\right)$.

Complementary measurements of pak choy rosette diameters were also taken. 'Taisai' rosettes were characterised by the greatest diameter in principle throughout the period of field cultivation. An interesting fact is that a greater variation in this parameter was observed in the second period of production. Regression equations for the evaluation of changes in diameter of the plants in relation to time were also characterised by a much larger accuracy for subsequent crops. And so the diameter of rosettes (y) could be calculated by the following equations: 'Taisai' $\mathrm{y}=25.2256+0.9857 * \mathrm{DAT}(\mathrm{R}=$ $0.819 ; \mathrm{R}^{2}=0.670$ ), 'Pak Choy White' $\mathrm{y}=18.0661$ $+0.9902 * \mathrm{DAT}\left(\mathrm{R}=0.835 ; \mathrm{R}^{2}=0.697\right)$, and 'Green Fortune' $\mathrm{F}_{1} \mathrm{y}=13.6339+0.8731$ * $\mathrm{DAT}(\mathrm{R}=0.849$; $\mathrm{R}^{2}=0.720$ ) in the earlier growing period, while in the production for later harvest the equations are as follows: 'Taisai' $\mathrm{y}=20.1953+0.9215^{*} \mathrm{DAT}(\mathrm{R}=$ 0.954; $\left.\mathrm{R}^{2}=0.911\right)$, 'Pak Choy White' $\mathrm{y}=17.2393$ $+0.7363^{*} \mathrm{DAT}\left(\mathrm{R}=0.911 ; \mathrm{R}^{2}=0.830\right)$, and 'Green Fortune' $\mathrm{F}_{1} \mathrm{y}=13.7373+0.6344 * \mathrm{DAT}(\mathrm{R}=0.947$; $\mathrm{R}^{2}=0.896$ ). 


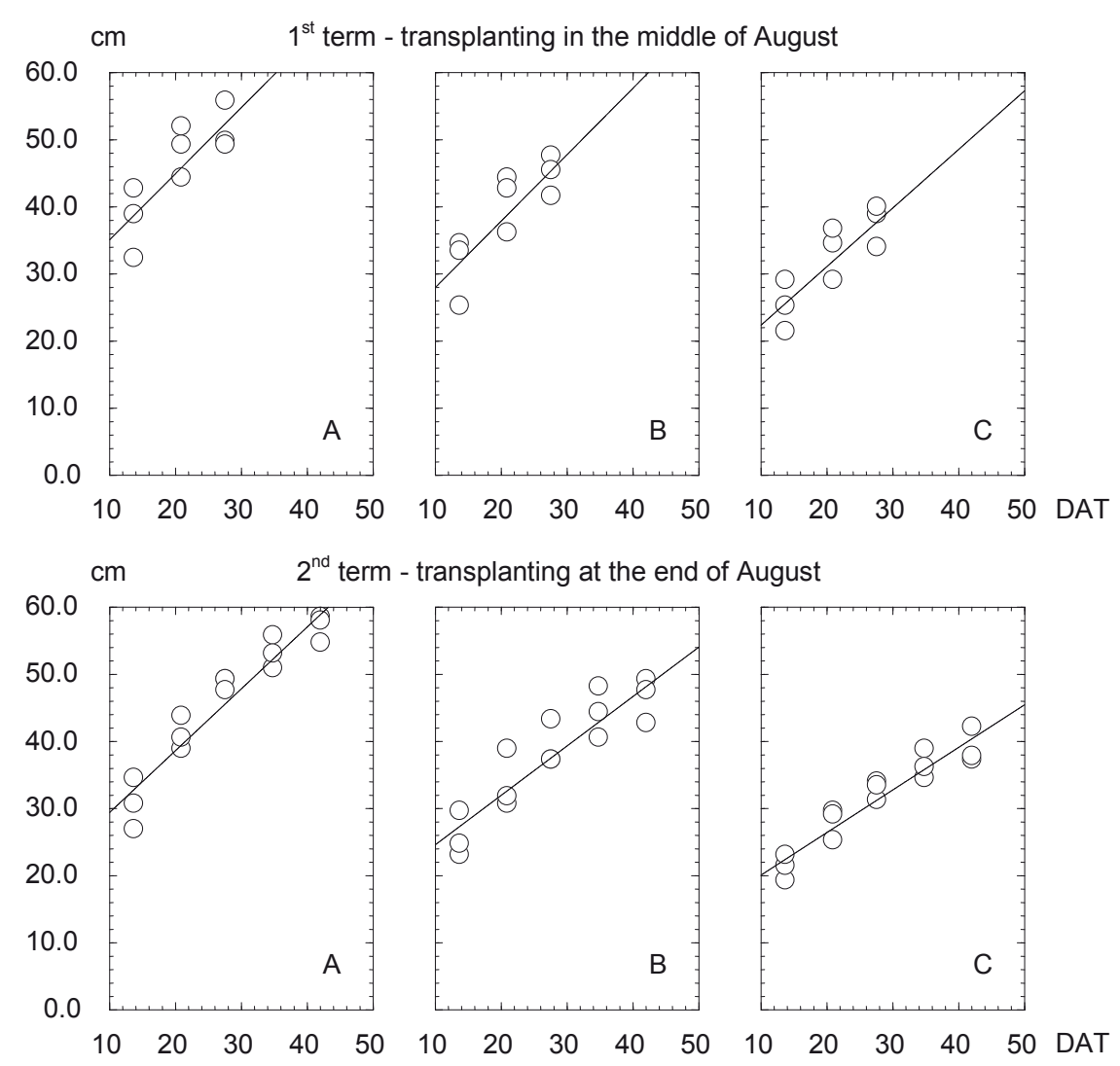

Figure 3. Rosette diameter of pak choy plants over time (DAT - days after transplanting) during field vegetation: A - 'Taisai', B - 'Pak Choy White', C - 'Green Fortune' $\mathrm{F}_{1}$

Estimating the growth pattern of the plants in the field only on the basis of the time variable gave valuable information, as it was possible to assess in a simple way the length of the crop vegetation period. In this case, any other environmental variables were not included. For plants growing briefly in the field, these models can be very precise. The ability to estimate the growth and development of the plants is especially important for species like pak choy. As a result of such models, we can obtain data about changes in the size of the crop rosettes, and indirectly about the approximate date of first harvest. Wurr et al. (1996) also used time as a criterion for assessing the developmental rate of growing point height of Chinese cabbage (Brassica pekinensis) heads as well as total plant fresh weight. Simulation models based on growth time of this vegetable crop cultivated in field conditions were tested by Zhang et al. (2007). These authors evaluated changes in the leaf area of the plants using the regression method and neural networks. Tei et al. (1996a, 1996b) had also used time as an independent variable in the equations made for lettuce, onions and beetroot plants. Olesen and Grevsen (2000) checked the accuracy of the developed models for leaf area, dry matter content and curd diameter of cauliflower using a time scale.

Stepwise regression analysis was used to simplify the model used for predicting the length of the pak choy vegetation period (LVP). The basic equation involves air temperature (minimum, mean and maximum) and also sunshine hours (data was averaged for particular production terms):

$\mathrm{LVP}=\mathrm{B}_{0}+\mathrm{B}_{1} * \mathrm{~T}_{\text {mean }}+\mathrm{B}_{2} * \mathrm{~T}_{\max }+\mathrm{B}_{3} * \mathrm{~T}_{\text {min }}+\mathrm{B}_{4} * \mathrm{Sun}_{\mathrm{d}}$ where $\mathrm{B}_{0}$ was intercept, $\mathrm{B}_{1}-\mathrm{B}_{4}$ were standardised regression coefficients, $T_{\max }, T_{\text {mean }}, T_{\min }$ were maximum, mean, and minimum air temperature (respectively) and $\operatorname{Sun}_{d}$ was sunshine hours. The analysis showed that mean air temperature and sunshine hours affected the growth and maturity of pak choy plants in the highest degree. The final model equation took the following form:

$$
\mathrm{LVP}=90.3795-1.7174 * \mathrm{~T}_{\text {mean }}-3.9408 * \text { Sun }_{\mathrm{d}}
$$

Statistics for the above regression model are presented in Table 1. Other parameters of the model evaluation are as follows: coefficient of determination $\mathrm{R}^{2}=0.962$; adjusted coefficient of determination $\mathrm{R}_{\text {adj }}^{2}=0.957(\mathrm{p}<0.000)$. The high accuracy of the obtained model should be pointed 
Table 1. Regression model for length of vegetation period (LVP) in relation to weather conditions during field production of pak choy

\begin{tabular}{lccccc}
\hline Equation parameters & B coefficient & Std. error B & $\beta$ coefficient & Std. error $\beta$ & $p$ \\
\hline Intercept & 90.3795 & 2.9218 & --- & --- & 0.0000 \\
$\mathrm{~T}_{\text {mean }}$ & -1.7174 & 0.3370 & -0.5238 & 0.1028 & 0.0001 \\
Sun $_{\mathrm{d}}$ & -3.9408 & 0.8263 & -0.4901 & 0.1028 & 0.0003 \\
\hline
\end{tabular}

$\mathrm{B}$ - standardised regression coefficient; $\beta$ - beta regression coefficient (slope); $\mathrm{p}$ - significance level

out. The standard error of estimation $\mathrm{SE}_{\mathrm{e}}$ for the LVP model was equal to 1.526 , i.e. in the estimation of the vegetation period of pak choy, the equations are accurate to an average of about 1.5 days.

The data presented in Table 1 showed that the slope (coefficients $\beta$ ) was negative. A graphic representation of the relationship between the length of the growing season for pak choy and average temperatures or sunshine hours is illustrated in Figure 4.

Lee (1996) and Weng et al. (1999) demonstrated the relationship between climatic conditions and the growth rate of Chinese cabbage. The former author described a strong and positive impact of solar radiation on plant growth and in consequence on the yield of pak choy and a negative plant response to the amount of rainfall. However, Weng et al. (1999) found that the rate of fresh weight production of that crop was mainly dependent on air temperature and precipitation, and to a lesser extent on solar radiation. These types of models, taking the standard meteorological data into account and evaluating the growth rate or yield acceleration, were presented by Francescangeli et al. (2004) for broccoli and Dufault et al. (2009) for Romaine lettuce, for example.

Growing degree days (GDD), heliothermal units (HTU) and photothermal units (PTU) can be other explanatory variables in models of plant maturity
(Everaarts 1999, Bazgeer et al. 2006, Kurtar 2006). In his review work, Everaarts (1999) described the results of the maturity prediction for several species: asparagus, broccoli, cauliflower, cabbage, kale, beans, peas, lettuce and radishes, which were based on effective temperatures (GDD). This type of model has been described by Grevsen and Olesen (1999) and Tan et al. (2000b) for broccoli and also by Grevsen and Olesen (1994) for cauliflower. The results of regression analysis made in the present experiment with pak choy for GDD, HTU and PTU are presented in Tables 2 and 3. The use of GDD as the independent variable resulted in an imprecise model. The obtained equation can predict the earliness of pak choy with a relatively high error $\mathrm{SE}_{\mathrm{e}}$; in addition, the model does not fit well $\left(\mathrm{R}^{2}\right.$ below 0.2). Francescangeli et al. (2004) reported the limited usefulness of effective temperature models compared to thermal ones to predict the maturity of broccoli. In the present study, the models that included temperature and also sunlight (actual and potential maximum for the day) provided greater precision. While the coefficients of determination in the case of PTU did not exceed 0.5, when using the HTU it reached a level above 0.8. The regression equation based on HTU was also characterised by the smallest standard error of estimation. The slope ( $\beta$ coefficient) for all models was negative. In other words, the smaller the value of the analysed
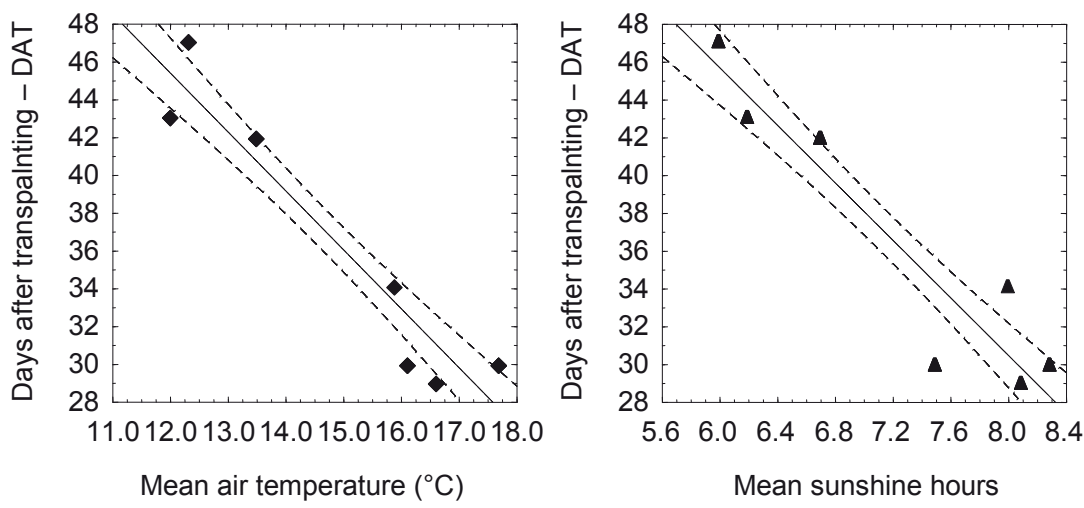

Figure 4. Relationships between length of pak choy vegetation period and mean air temperature or mean sunshine hours 
Table 2. Statistics of regression models for pak choy earliness depending on growing degree days (GDD), heliothermal units (HTU) and photothermal units (PTU)

\begin{tabular}{lccccc}
\hline Variables & Equation & $\mathrm{R}$ & $\mathrm{R}^{2}$ & $\mathrm{R}_{\text {adj }}^{2}$ & $\mathrm{SE}_{\mathrm{e}}$ \\
\hline GDD & $\mathrm{y}=69.3212-0.0918^{*} \mathrm{GDD}$ & 0.183 & 0.136 & 0.000 & 8.350 \\
HTU & $\mathrm{y}=82.7884-0.0188^{*} \mathrm{HTU}$ & 0.918 & 0.843 & 0.804 & 3.558 \\
PTU & $\mathrm{y}=85.6466-0.0105 *$ PTU & 0.696 & 0.485 & 0.356 & 6.449 \\
\hline
\end{tabular}

$\mathrm{R}$ - multiple coefficient of regression; $\mathrm{R}^{2}$ - coefficient of determination; $\mathrm{R}_{\text {adj }}^{2}$ - adjusted coefficient of determination; $\mathrm{SE}_{\mathrm{e}}-\mathrm{standard}$ error of estimation

Table 3. Summary of regression for earliness of pak choy based on GDD, HTU and PTU

\begin{tabular}{llccccc}
\hline Equation parameters & & $\mathrm{B}$ & Std. error B & $\beta$ & Std. error $\beta$ & $\mathrm{p}$ \\
\hline \multirow{2}{*}{ Growing degree days } & Intercept & 69.3212 & 41.0479 & --- & --- & 0.1665 \\
& GDD & -0.0918 & 0.1156 & -0.3691 & 0.4647 & 0.4715 \\
\multirow{3}{*}{ Heliothermal units } & Intercept & 82.7884 & 10.0166 & --- & --- & 0.0012 \\
& HTU & -0.0188 & 0.0041 & -0.9182 & 0.1980 & 0.0098 \\
Photothermal units & Intercept & 85.6466 & 25.2987 & --- & --- & 0.0277 \\
& PTU & -0.0105 & 0.0054 & -0.6963 & 0.3589 & 0.1244 \\
\hline
\end{tabular}

$\mathrm{B}$ - standardised regression coefficient; $\beta$ - beta regression coefficient (slope); $\mathrm{p}$ - significance level

independent variables (HTU, PTU, GDD), the longer the growing period of the pak choy plants could be expected.

\section{REFERENCES}

Bazgeer S., Mahey R.K., Sharma P.K., Sood A., Sidhu S.S., 2006. Pre-harvest wheat yield prediction using agromet-spectral-trend-yield models for Hoshiarpur and Rupnagar districts of Punjab. J. Indian Soc. Remote Sens. (34)3: 269-277.

Cebula S., Kalisz A., Kunicki E., 2003. Przebieg wzrostu i plonowania kalafiora białego, zielonego i romanesco $\mathrm{w}$ dwóch terminach uprawy na zbiór jesienny. Folia Hort. Suppl. 2003/2: 302-304.

Cebula S., Kalisz A., Kunicki E., 2005. The course of growth and yielding of white and green cauliflower cultivated in two terms for autumn production. Folia Hort. 17(1): 23-35.

Сно Y.Y., Son J.E., 2007. Estimation of leaf number and leaf area of hydroponic pak-choi plants (Brassica campestris ssp. chinensis) using growing degreedays. J. Plant Biol. 50(1): 8-11.

Dufault R.J., Ward B., Hassell R.L., 2009. Dynamic relationships between field temperatures and romaine lettuce yield and head quality. Sci. Hort. 120: 452459.

EveraARTs A.P., 1999. Harvest date prediction for field vegetables. A review. Gartenbauwissenschaft 64(1): 20-25.

Francescangeli N., Sangiacomo M.A., Martí H.R., 2006. Effects of plant density in broccoli on yield and radiation use efficiency. Sci. Hort. 110: 135-143.

Francescangeli N., Stoppani M.I., Martí H.R., 2004. Aptitud de modelos de temperaturas y de tiempo térmico en broccoli (Brassica oleracea var. italica). Agriscientia XXI(2): 51-57.

Granges A., 1989. Le pak-choï, un nouveau legume á cultiver toute l'année. Revue Suisse Vitic. Arboric. Hortic. 21(1): 35-38.

Grevsen K., Olesen J.E., 1994. Modelling cauliflower development from transplanting to curd initiation. J. Hort. Sci. 69(4): 755-766.

Grevsen K., Olesen J.E., 1999. Modelling development of broccoli (Brassica oleracea L. var. italica) from transplanting to head initiation. J. Hort. Sci. Biotech. 74(6): 698-705.

Hoogenboom G., 2000. Contribution of agrometeorology to the simulation of crop production and its applications. Agr. Forest Meteorol. 103: 137-157.

Kalisz A., 2004. Przydatność kilku odmian kapusty chińskiej (Brassica chinensis) do uprawy na zbiór jesienny. Now. Warz. 39: 105-110.

Kumar A., Pandey V., Shekh A.M., Kumar M., 2008. Growth and yield response of soybean (Glycine $\max$ L.) in relation to temperature, photoperiod and sunshine duration at Anand, Gujarat, India. AmerEurasian J. Agron 1(2): 45-50.

Kurtar E.S., 2006. The effect of planting times on some vegetable characters and yield components in Brussels sprouts (Brassica oleracea var. gemmifera). J. Agron. 5(2): 186-190.

LEE L.F., 1996. Effects of climatic factors on the yield of pak-choi in I-Lan area. Chin. J. Agrometeorol. 3(4): 217-221.

Marcelis L.F.M., Heuvelink E., GoudriaAn J., 1998. Modelling biomass production and yield of horticultural crops: a review. Sci. Hort. 74: 83-111.

Martyniak-Przybyszewska B., 2000. Wpływ terminu uprawy na plonowanie odmian kapusty pekińskiej 
(Brassica pekinensis Rupr.). Ann. UMCS Sec. EEE VIII: 87-93.

McMaster G.S., Wilhelm W.W., 1997. Growing degreedays: one equation, two interpretations. Agr. Forest Meteorol. 87: 291-300.

Niedbala G., Przybye J., Sęk T., 2007. Prognozowanie zawartości cukru w korzeniach buraka cukrowego $\mathrm{z}$ wykorzystaniem technik regresyjnych i neuronowych. Inż. Rol. 2(90): 225-234.

Olesen J.E., Grevsen K., 2000. A simulation model of climate effects on plant productivity and variability in cauliflower (Brassica oleracea L. botrytis). Sci. Hort. 83: 83-107.

Siomos A., 1999. Planting date and within-row plant spacing effects on pak choi yield and quality characteristics. J. Veg. Crop. Prod. 4(2): 65-73.

TAN D.K.Y., Birch C.J., Wearing A.H., Rickert K.G., 2000a. Predicting broccoli development. I. Development is predominantly determined by temperature rather than photoperiod. Sci. Hort. 84: 227-243.

Tan D.K.Y., Birch C.J., Wearing A.H., Rickert K.G., 2000b. Predicting broccoli development. II. Comparison and validation of thermal time models. Sci. Hort. 86: 89-101.

Tei F., Scaife A., Aikman D.P., 1996a. Growth of lettuce, onion, and red beet. 1. Growth analysis, light interception, and radiation use efficiency. Ann. Bot. 78: 633-643.

Tei F., Aikman D.P., Scaife A., 1996b. Growth of lettuce, onion, and red beet. 2. Growth modelling. Ann. Bot. 78: 645-652.

Weng J.-H., Hsu Y.-P., Kuo F.-Y., Lin W.-J., 1999. Effects of climatic factors on the growth rate of pakchoi. Chin. J. Agrometeorol. 6(1): 7-14.

Wurr D.C.E., Fellows J.R., Phelps K., 1996. Growth and development of heads and flowering stalk extension in field-grown Chinese cabbage in the UK. J. Hort. Sci. 71(2): 273-286.

Wurr D.C.E., Fellows J.R., Phelps K., 2002. Crop scheduling and prediction - principles and opportunities with field vegetables. Adv. Agron. 76: 201-234.
ZhANG W., BAI C., LIU G., 2007. Neural network modelling of ecosystems: a case study on cabbage growth system. Ecol. Model. 201: 317-325.

\section{WZROST I WCZESNOŚĆ KAPUSTY CHIŃSKIEJ (BRASSICA RAPA VAR. CHINENSIS) JAKO FUNKCJA CZASU I WARUNKÓW POGODOWYCH}

Streszczenie: Celem badań, prowadzonych w latach 2003-2005, była ocena możliwości stworzenia modeli regresyjnych dla przewidywania wczesności plonowania kapusty chińskiej (Brassica rapa var. chinensis, pak choy) uprawianej w polu $\mathrm{w}$ miesiącach letnio-jesiennych. Cztery zmienne (minimalna, średnia i maksymalna temperatura oraz usłonecznienie) zostały wybrane do budowy modelu prognostycznego. $\mathrm{Za}$ pomocą analizy regresji krokowej stwierdzono, że wczesność tego warzywa może być opisywana jako funkcja średniej temperatury powietrza i usłonecznienia. Dla tego modelu współczynnik determinacji $\mathrm{R}^{2}$ był równy 0,962. Dodatkowe modele, bazujące na wskaźnikach termicznych takich jak stopniodni (GDD), jednostki heliotermiczne (HTU) lub fototermiczne (PTU) zostały również skonstruowane i wzięte pod uwagę. Równanie regresji prostej oparte na GDD może symulować wczesność tych roślin z precyzją nie przekraczającą $14 \%$. Z kolei model zbudowany na podstawie PTU wykazał znacznie lepsze dopasowanie danych prognozowanych do obserwowanych (rzędu około 49\%). Najlepszym dopasowaniem cechował się model wykorzystujący jednostki HTU ( $\mathrm{R}^{2}$ wynosił 0,843 ). Modele czasowe dla przebiegu wzrostu roślin pak choy podczas ich wegetacji $\mathrm{w}$ polu zostały również zaprezentowane w niniejszej publikacji.

Received June 14, 2010; accepted December 9, 2011 